\title{
Liquid Biomarkers for Pediatric Brain Tumors: Biological Features, Advantages and Perspectives
}

\author{
Sibylle Madlener * and Johannes Gojo \\ Comprehensive Center for Pediatrics, Department of Pediatrics and Adolescent Medicine, \\ Medical University of Vienna, 1090 Vienna, Austria; johannes.gojo@meduniwien.ac.at \\ * Correspondence: sibylle.madlener@meduniwien.ac.at
}

Received: 23 October 2020; Accepted: 24 November 2020; Published: 27 November 2020

check for updates

\begin{abstract}
Tumors of the central nervous system are the most frequent solid tumor type and the major cause for cancer-related mortality in children and adolescents. These tumors are biologically highly heterogeneous and comprise various different entities. Molecular diagnostics are already well-established for pediatric brain tumors and have facilitated a more accurate patient stratification. The availability of targeted, biomarker-driven therapies has increased the necessity of longitudinal monitoring of molecular alterations within tumors for precision medicine-guided therapy. Nevertheless, diagnosis is still primarily based on analyses of the primary tumor and follow-up is usually performed by imaging techniques which lack important information on tumor biology possibly changing the course of the disease. To overcome this shortage of longitudinal information, liquid biopsy has emerged as a promising diagnostic tool representing a less-invasive source of biomarkers for tumor monitoring and therapeutic decision making. Novel ultrasensitive methods for detection of allele variants, genetic alterations with low abundance, have been developed and are promising tools for establishing and integrating liquid biopsy techniques into clinical routine. Pediatric brain tumors harbor multiple molecular alterations with the potential to be used as liquid biomarkers. Consequently, studies have already investigated different types of biomarker in diverse entities of pediatric brain tumors. However, there are still certain pitfalls until liquid biomarkers can be unleashed and implemented into routine clinical care. Within this review, we summarize current knowledge on liquid biopsy markers and technologies in pediatric brain tumors, their advantages and drawbacks, as well as future potential biomarkers and perspectives with respect to clinical implementation in patient care.
\end{abstract}

Keywords: pediatric cancer; brain tumor; liquid biopsy; cerebrospinal fluid; ddPCR; biosensor; next-generation sequencing (NGS); miRNA

\section{Introduction}

1.1. General Information to Pediatric Brain Tumors, Diagnosis, Prognosis, Treatment and Clinical Benefit of Liquid Biopsy

Tumors of the central nervous system (CNS) are the most frequent solid tumor type in children and adolescents and exhibit the highest mortality rate of pediatric cancer types [1]. Although the overall prognosis of pediatric brain tumors is more favorable than in adults, their high contribution to cancer-related mortality in children can be attributed to the high aggressiveness of certain subtypes including high-grade glioma (HGG), medulloblastoma (MB), ependymoma (EPN) and other rare tumor types such as atypical teratoid rhaboid tumors (ATRT) or embryonal tumors with multilayered rosettes (ETMR) [2]. These entities account for approximately one third of pediatric brain tumors and are currently treated with intense therapeutic regimens which, however, are still not curative in 
a substantial proportion of cases [1,2]. These therapies are mostly based on radiotherapy as well as chemotherapy and differ in between entities [2]. Importantly, these highly toxic therapies may also result in substantial therapy-associated sequelae including amongst others risk of secondary malignancies, endocrinopathies and impaired neurological development [3]. Current classification is based on the "2016 World Health Organization Classification of Tumors of the Central Nervous System" [4] which implemented molecular markers in the diagnosis of pediatric brain tumors. Thus, tissue biopsy and magnetic resonance imaging (MRI) are the current gold standard methods for pediatric brain tumor diagnosis [5] as well as for longitudinal monitoring during therapy and follow-up. However, tissue biopsies are mostly taken at a single time point, mostly at primary diagnosis of the tumor, and only represent the molecular composition of the primary tumor. Furthermore, follow-up by MRI is feasible to monitor tumor size and recurrence but lacks the detailed information of molecular alterations during tumor evolution. In addition, the availability of targeted therapy has increased the need for longitudinal monitoring of molecular changes within tumors in order to precisely guide anti-cancer treatment. Hence, there is a compelling need for the indirect assessment of tumors at certain time points via less-invasive tumor markers which can be gained from body fluids of the patient [6,7]. The most proximal source for liquid biopsy for pediatric brain tumors is the cerebrospinal fluid (CSF) followed by peripheral blood including its components serum/plasma and urine [8] (Figure 1). Diverse biological specimens are detectable within these body fluids by multiomics approaches and may be specific for different brain tumor types.

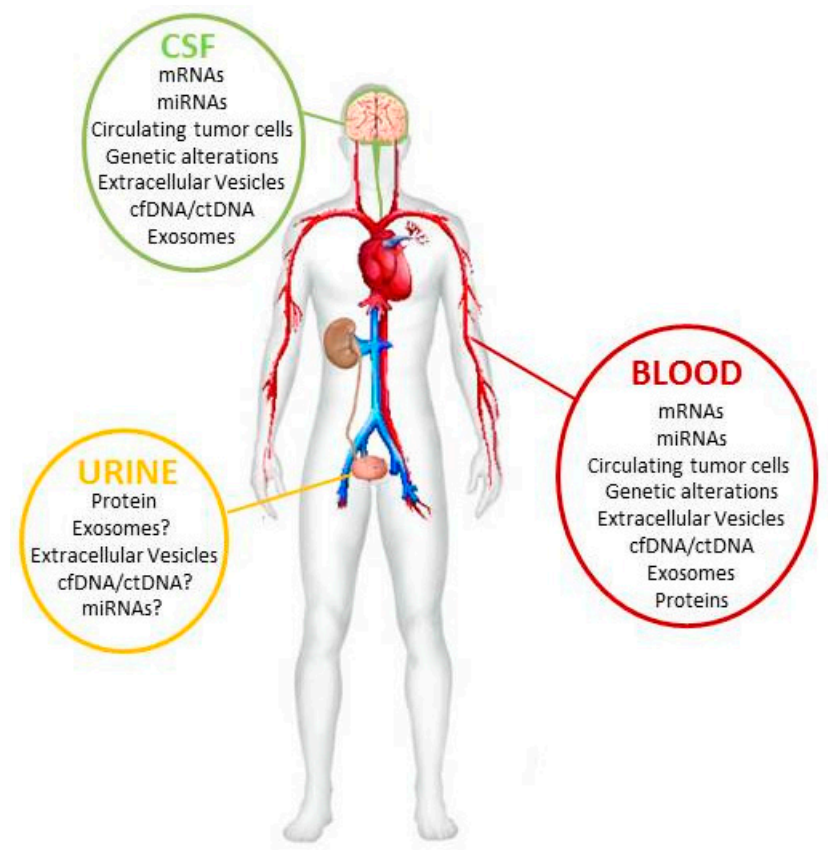

Figure 1. Schematic overview.

\subsection{Liquid Biopsy in General}

Over the last decade substantial progress has been made in the understanding of the molecular pathogenesis of pediatric brain tumors through multi-omics screening methods [9-17] and the discovery of novel and sensitive screening methods reveals a great opportunity for liquid biomarkers. Multiple different molecular structures have been identified in the liquids of pediatric brain tumor patients and raised the interest of the scientific field. These biomarkers include circulating tumor cells (CTCs) [18,19], circulating tumor DNA (ctDNA) [7,18,19], cell-free DNA (cfDNA) [6,18-21], circulating proteins [6,8,19,20], extracellular vesicles and exosomes [5,18,22-26], micro-RNAs (miRNAs) [5,19,27-32], long non-coding RNA (lncRNA) [33] and other genetic alterations [28,34-38]. Detection of these biomolecules may offer advantages compared to surgical 
interventions. Nevertheless, there are still some challenging limitations for the clinical application with respect to standardized isolation protocols and sensitive methods. These pitfalls will be addressed in the second chapter.

\subsubsection{Circulating Tumor Cells}

Circulating tumor cells were described and documented in the blood of a patient with metastatic disease for the first time in 1869 in Australia [39,40]. Moreover, detection of tumor cells in CSF via cytology is routinely used for staging of certain pediatric brain tumor types. Any detection of circulating tumor cells in body fluids from patients provides a direct evidence of tumor spreading and metastasis [19] and may be used as an early biomarker to predict tumor diagnosis, progression and its dissemination [41]. Through shedding into the CSF or blood vessels, the collection and isolation of these tumor cells from the liquids is a simple and less-invasive intervention for tumor monitoring and clinical treatment decisions. Another important advantage of circulating tumor cells over ctDNA and cfDNA is the longer half-life of these cells which ranges from 1-2.4 $\mathrm{h}$ [42] in taken blood or CSF samples. Therefore, detection of circulating tumor cells might be a good and almost stable real-time marker for tumor surveillance [41].

\subsubsection{Cell Free/Circulating Tumor DNA (cf/ctDNA)}

DNA fragments originating from cells outside of the blood circulation are known to be found in the bloodstream and other bio-fluids from patient and healthy humans. They are released from the cells into the fluids by several cellular processes, such as apoptosis or necrosis, respectively [40,43]. Usually, cf/ctDNA appears in combination with other biomolecules in the form of a protein complex. The size of ctDNA ranges from 70 to $200 \mathrm{bp}$, a longer DNA fragment than normal cfDNA [43]. They are also released randomly into microvesicles or exosomes and carried to other cells [44]. These short DNA sequences offer the perfect transcript for the direct detection of any genetic alterations, mutations or single nucleotide variants by using highly sensitive methods which are now available and will be described in detail within the next part of the article. With respect to adult brain tumors, Li et al. demonstrated that CSF derived ctDNA better reflect the mutations in driver genes compared to plasma ctDNA in glioblastoma patients. This result is partly explained by the high concentration of ctDNA in CSF and its low concentration in plasma because of the blood brain barrier [45]. However, the clearance of these small DNA sequences in the bloodstream and CSF are not complete understood and need to be investigated in more detail. Nonetheless, there are many open questions before ct/cfDNA will be used as a routine biomarker including stability, degradation and concentration in the liquids as well as specific isolation kits for these small DNA fragments.

\subsubsection{Extracellular Vesicles/Exosomes}

Several studies have demonstrated that multiple cells, including tumor cells and tumor stem cells, release extracellular vesicles and exosomes and internalize exosomes secreted from other cells [46-50]. They originate from multivesicular bodies and are discharged via p53- regulated exocytosis [51]. During their composition they pack active and selective several cellular structures, such as miRNA, mRNA, lncRNA, proteins, DNA, or lipids [44,52], respectively, and deliver them to other cells [53]. Exosomes represent a cargo tool between cellular complexes and have the ability to cross the blood brain barrier [54] as shown in different xenograft models [55-57]. This approach offers a broad spectrum for diagnostic and prognostic biomarker studies. Furthermore, the exosomal miRNA content is a hallmark of tumor cell types and the incorporation of miRNAs, respectively, is highly specific $[5,58]$ to cancer cells. During past years, treatment abilities of exosomes loaded with specific active biomolecules like miRNAs have been tested in different clinical trials for cancer immunotherapy [59]. 


\subsubsection{Micro-RNA (miRNA)}

Micro-RNAs constitute an evolutionary highly conserved class of non-coding RNAs that play key roles in the regulation of gene expression. They are genome-encoded short, single-stranded approximately 22 nucleotide-long RNA molecules that silence or contribute to degradation of mRNA by binding to $3^{\prime}$-untranslated regions of mRNAs. Their complete function is not yet fully understood, but recent research has shown small, non-coding microRNAs to be master regulators of cellular processes, and expression patterns have revealed their potential as diagnostic, prognostic, and treatment response biomarkers [60]. Furthermore, miRNAs appear to be extremely stable outside the cells and can be easily detected in extracellular space [61], extracellular vesicles and exosomes [5], or in other types of body fluid such as blood, urine, breast milk, CSF, cyst fluids [62-64]. Therefore, miRNAs are particularly suitable as clinical biomarkers for early detection of disease, monitoring cancer progression and therapeutic response [63].

\section{Sample Handling and the Major Challenge and Pitfall for Sufficient Liquid Biopsy Detection}

As already mentioned, the extensive interest in detailed knowledge from the molecular biology of pediatric brain tumors and the trend to precision medicine has fueled development of novel molecular methods in pathology. Technological developments and advances of extremely sensitive and reliable methods have improved the feasibility of analyzing liquid biopsy samples from brain tumor patients. However, there are still certain challenges and pitfalls to avoid false positive or negative results. In this chapter, we will discuss the major pitfalls of liquid biopsy.

The quality and handling of the liquid biopsy sample is an important point in the pre-analytical phase. The stability of liquid biopsy markers and structures are mainly affected by several steps during the pre-clinical workflow, such as what kind of blood collection tube is used followed by the storage temperature and time-to-processing as well as centrifugation speed [65]. All these factors could cause a reduction of stability and concentration of these easy to obtain, but fragile biomarkers. Therefore, a standard operating procedure is urgently needed for the pre-analytical phase to reach reliable and good comparable results within different routine labs.

\subsection{Circulating Tumor Cells}

Beside the pre-analytical pitfalls in handling of body fluids, circulating tumor cells are represented in an extreme low concentration in liquid biopsy samples in early stage tumors [66]. Especially in pediatric brain tumor patients, drawing large volumes of liquids is almost impossible. Therefore, an adaption of the circulating tumor cell isolation is inevitable. In 2016, Gorges and colleagues tested an in vivo device for the isolation of circulating tumor cells from a lung cancer patient. They validated the CellCollector from GILUPI (GMBH, Potsdam, Germany) that enables the isolation of circulating tumor cells direct from the arm vein of the patient. The wire from the CellCollector surface is modified and coated with anti-EpCam antibodies and only EpCam positive cells will bind. During the incubation of $30 \mathrm{~min}$ the modified wire is exposed to approximately $1 \mathrm{~L}$ of blood, thereby an increasing concentration of circulating tumor cells was achieved [67]. This new device might be the promising tool to isolate sufficient circulating tumor cells in all kind of tumor patients.

\subsection{Cell Free/Circulating Tumor DNA (cf/ctDNA)}

The major challenge of using cf/ctDNA for liquid biopsies is their extremely low abundance in serum. Depending on the tumor stage, the ctDNA ranges between $0.01 \%$ to more than $10 \%$ in total isolated cfDNA [68]. To increase the stability and avoid the degradation of these rare DNA structures, specific coated collection tubes are needed. In 2019, Sese and colleagues tested and validated cell-free DNA collection tubes for their usage in liquid biopsy. They obtained blood from a lung cancer patient and shipped the processed samples to the Vall d'Hebron Hospital by two different methods in parallel: (1) cell free DNA blood collection tubes from Roche, shipped at room temperature; 
and (2) in standard $\mathrm{K}_{2}$ EDTA blood collection tubes with centrifuged plasma, shipped frozen on dry ice. Thereafter, they analyzed the Epidermal growth factor receptor (EGFR) mutation status and demonstrated the same high significance and concordance of the cell free DNA tubes shipped on room temperature as the current method ( $\mathrm{K}_{2}$ EDTA blood collection tube). In summary, the simple handling of the cell-free DNA collection tubes for the shipping and storage on room temperature for up to 5 days indicates a preferable method for future clinical settings in routine labs [69]. The isolation method of cell-free nucleic acid is another crucial pre-analytical step for liquid biopsy. In 2020, Kerarchian et al. demonstrated a significant difference in the methods according to sensitivity in the downstream analysis. They compared the silica membrane isolation gold standard for $\mathrm{cf} / \mathrm{ctDNA}$ isolation from liquids with the "selective capture of ctDNA on magnetic beads" method (SCC-MAG) [70]. Beside the increased detection values in polymerase chain reaction (PCR)-based methods in the downstream workflow, this new technique was capable of isolating sufficient ctDNA from hemolytic samples. The SCC-MAG technology can be applied to any specific DNA sequence. In their respective study, the authors analyzed the specific mutations of KRAS in ctDNA isolated from patient serum samples.

\subsection{Exosomes}

In general, exosomes are extreme stable in the bloodstream and would be the perfect liquid biopsy tool. Their content includes miRNAs, proteins and, recently, researchers discovered the presence of dsDNA from the parental tumor cell [71]. Certainly, there are still problems in the clean filtration and isolation of the exosomes. Beside their tendency to bind on plasma proteins, they are extreme sticky to common laboratory plastic thereby reducing the isolated concentration [72]. Even the time from the blood draw to the isolation procedure negatively manipulates the number of collected exosomes. Hence, more progress in the development of sensitive and reproducible methods is needed before exosomes could be introduced into clinical routine.

\subsection{Micro-RNA (miRNA)}

Micro-RNAs have been found to be stable within extracellular vesicles and exosomes isolated from CSF and plasma samples. Balzano and colleagues addressed the question of the stability of miRNAs in frozen vs. fresh plasma samples [73]. There, they evaluated the miRNA concentration of fresh plasma samples compared to frozen samples after 6 and 12 months of storage at $-80{ }^{\circ} \mathrm{C}$. In addition, they included and evaluated plasma samples stored at $-80^{\circ} \mathrm{C}$ and collected in 1999 , 2002, 2003, 2009 and 2010. They observed no significant differences of the miRNA values between the fresh and 6-month frozen samples. Interestingly, only one miRNA (miR126-3p) showed a lower concentration in the years 2010, 2009, 2003, and 2002 compared to the fresh plasma samples. All other miRNAs had no significant differences in these years. They explained that the stability of miRNAs is related to the absence of the AU sequence in the seed and tail miRNA regions [73] and is not generally connected to time.

\section{Sensitive Methods}

In this chapter we discuss the latest findings of sensitive techniques for the detection of markers in liquid biopsies

\subsection{Next-Generation Sequencing (NGS)}

Next-generation sequencing (NGS)-based technologies provide high-throughput screening of the biopsy samples and improved accuracy with respect to mutation allele frequency (MAF), gene fusions or DNA amplification [74,75]. As previously described, NGS methods can be applied to targeted panel systems for detection of targeted ctDNA mutations and indels. These panels are namely Safe-Sequencing System (Safe-SeqS), Cancer Personalized Profiling by deep sequencing (CAPP-Seq), Ion Torrent and Tagged-Amplicon deep sequencing (TAm-Seq) [74]. Gale et al. published in 2018 an improved version of the TAm-Seq based NGS and named it eTAm-Seq technology. They investigated 
the InVision liquid biopsy platform with eTAm Seq and increased the detection of low-frequency mutations in cfDNA. The novel enhanced system can detect MAF as low as $0.25 \%$ with a sensitivity of $94 \%$ compared to the normal TAm-Seq (MAF 2\% and 97\% sensitivity) $[75,76]$. Targeted panel sequencing represents low-cost and high sensitivity to point mutation in liquids, but lacks detection of whole genome sequencing (WGS) or whole exome sequencing (WES). These methods provide a complete profile of the tumor DNA or exome DNA including point mutations, indels, rearrangements, copy number variations (CNV) and DNA amplification. However, WGS and WES are pricy and both sequencing technologies are less sensitive and need a high amount of sample input. This essential aspect impedes their usage for liquid biopsy applications in early tumor diagnosis when ctDNA concentration is known to be low in the patient liquids.

\subsection{Digital Polymerase Chain Reaction (dPCR) and Digital Droplet PCR (ddPCR)}

Over the past decade, substantial progress has been made in the development of more sensitive PCR-based methods. The new explored APCR and ddPCR $[35,75]$ methods are ultrasensitive and low-cost techniques with respect to sequencing analysis. Furthermore, they are able to detect allele variants or targets with low abundance in samples that are below the limit of conventional quantitative PCR (qPCR) methods. In the last few years, several studies demonstrated this detection limit of rare events (mutation, CNV, miRNAs or other cell-free analytes $[6,18,35,37,38,77]$ ) in liquid biopsy samples. However, PCR-based methods are limited to screening already known targets and by sample input and speed.

\subsection{Electrochemical Biosensors}

During the last few years, the electrochemical biosensor technology has made substantial progress in the sensitive detection of nucleic acids in liquid biopsy samples [78,79]. Until 2015, the detection of $\mathrm{cf} / \mathrm{ctDNA}$ in liquids with electrochemical biosensors was still challenging. Das et al. improved the technology by combining a specific electrochemical clamp assay [80] with new surface nanostructure, and DNA probe design. They mixed isolated ctDNA from patient samples with peptide nucleotide acids (PNA) clamps for main known KRAS mutation and wild type and hybridized the sample. The clamp sequence for the mutation (target) of interest was excluded in the mixture. Thereafter, the heterogeneous solution including ctDNA and binding partners were applied to the PNA probe-modified microsensor. The target sequence lacking clamp partner hybridized to the PNA probes on the modified nanostructured microchip. Beside the specific PNA design, Das and colleagues coated the Au nanostructure chip with a thin layer of Pd to obtain nanostructured microelectrodes and reached a higher sensitivity of the binding and measured finely the differential pulse voltammetry (+target or -target). They tested this new assay design successfully in undiluted serum samples of lung and melanoma cancer patients [80].

Recently, another breakthrough in the development of electrochemical microfluidic biosensors was achieved. Bruch et al. in cooperation with our group developed a microfluidic chip combined with the novel Clustered Regularly Interspaced Short Palindromic Repeats (CRISPR/Cas13a) technology [81,82]. This system features a highly sensitive and selective detection tool for numbers of different targets. In a first study it allowed the detection and quantification of tumor miRNA-19b in serum samples from medulloblastoma patients without any amplification step. In addition, the complete process of analyzation was performed in less than $4 \mathrm{~h}$ and for successful measurements, a minimum sample volume of $0.6 \mu \mathrm{L}$ was used. All results were validated with the current qPCR-based gold standard for miRNA detection. The next step of Bruch and colleagues will be the development of a multiplexed CRISPR/Cas13a biosensor for analyzing miRNAs in patient samples at once. This improvement will provide a multiple accessible and low-cost tool for fast detection of nucleic acids in liquid biopsy samples. 


\section{Potential Liquid Biopsy Markers for Specific Brain Tumor Entities}

Having high potential for improved patient management, several studies have already investigated different methods for liquid biomarker detection in pediatric brain tumors. The following section and Table 1 summarize the current status for each entity and provide an outlook for potential molecular aberrations which could be leveraged as biomarkers in the future.

Table 1. Published and potential liquid biopsy biomarkers.

\begin{tabular}{|c|c|c|c|c|}
\hline & Biomarker & Source & Method & Literature \\
\hline \multicolumn{5}{|l|}{ Ependymoma } \\
\hline Genomic & $\begin{array}{l}\text { DNA methylation, } \\
\text { gene fusions (RELA-, } \\
\text { YAP), CNA (1q, 5p, } \\
\text { CDKN2A) }\end{array}$ & blood/CSF & $\begin{array}{c}\text { NGS, } d d P C R, \\
\text { methylation array }\end{array}$ & \\
\hline \multicolumn{5}{|l|}{ Glioma } \\
\hline Genomic & $\begin{array}{c}\text { DNA methylation, } \\
\text { Mutations (e.g., BRAF, } \\
\text { H3F3A, HIST3B), } \\
\text { CNAs (e.g., CDKN2A), } \\
\text { Fusions (e.g., NTRK) }\end{array}$ & blood/CSF & $\begin{array}{l}\text { NGS, ddPCR, } \\
\text { methylation array }\end{array}$ & {$[34,35,37,83]$} \\
\hline miRNA & $\begin{array}{l}\text { miR-21, miR-15b, } \\
\text { miR-23a, miR-146b }\end{array}$ & blood/CSF & & {$[30,84]$} \\
\hline Proteomics & bFGF, TIMP3 & Urine & ELISA & [8] \\
\hline \multicolumn{5}{|l|}{ Medulloblastoma } \\
\hline Genomic & $\begin{array}{l}\text { DNA methylation, } \\
\text { somatic mutations } \\
\text { (CNNB1, TERT } \\
\text { promoter, PTCH1 and } \\
\text { others), CNA } \\
\text { (monosomy 6, Gli2, } \\
\text { MYCN, MYC) }\end{array}$ & blood/CSF & $\begin{array}{c}\text { NGS, ddPCR, } \\
\text { methylation array }\end{array}$ & \\
\hline lipidomics & lipid profiles in CSF & CSF & lipidomics & [85] \\
\hline protein & PDG2S, IGFBP3 & CSF & ELISA & {$[86,87]$} \\
\hline miRNA & miRNA profiles & blood/CSF & NGS & \\
\hline \multicolumn{5}{|l|}{ Rare tumors } \\
\hline \multicolumn{5}{|l|}{ ATRT } \\
\hline Genomic & $\begin{array}{l}\text { DNA methylation, } \\
\text { Mutations (SMARCB1), } \\
\text { DNA methylation }\end{array}$ & & $\begin{array}{l}\text { NGS, ddPCR, } \\
\text { methylation array }\end{array}$ & \\
\hline Protein & Osteopontin & blood/CSF & ELISA & [88] \\
\hline ETMR & $\begin{array}{c}\text { DNA methylation, } \\
\text { CNA (C19MC), } \\
\text { Mutations (DICER1), } \\
\text { miRNA }\end{array}$ & & $\begin{array}{c}\text { NGS, ddPCR, } \\
\text { methylation array }\end{array}$ & \\
\hline HGNET-BCOR & $\begin{array}{l}\text { BCOR internal tandem } \\
\text { duplication }\end{array}$ & & NGS & \\
\hline
\end{tabular}

CSF, cerebrospinal fluid; NGS, next-generation sequencing; ddPCR, digital-droplet polymerase chain reaction (PCR); ELISA, enzyme-linked immunosorbent assay. 


\subsection{Glioma}

Low- and high-grade gliomas cover a wide clinical spectrum ranging from long-term treatment and follow-up to highly aggressive tumors with limited treatment options and short overall survival. Molecular analyses have revealed distinct genomic drivers and uncovered inter- as well as intratumoral heterogeneity within this entity. Importantly, the majority of low-grade gliomas is driven by alteration of the BRAF-pathway (BRAF-fusions, mutations) which are promising candidates for liquid biopsy tumor detection. These alterations (e.g., BRAFV600E-muation) may also be found in a subset of high-grade glioma. Indeed, first reports demonstrate that detection of BRAFV600E in liquid biopsies is feasible $[35,38,89]$. However, sensitivity in blood ranges from $25-50 \%$ suggesting that further improvement of the techniques is necessary [38]. This is of importance as targeted therapies against BRAFV600E exist and have been shown to effectively inhibit tumor growth in these patients $[90,91]$. Thus a sensitive detection method could aid in therapy decision and monitoring of the respective cases. Another major oncogenic driver found in gliomas are mutations within histones (H3F3A, HIST3B) which are frequently found in the midline and are thus not suitable for resection or re-biopsies. Consequently, the possibility of other means for monitoring tumor development appears important. H3K27M-mutations have been shown to be reliable detected in both blood and CSF $[34,35,37,83]$. Whereas the sensitivity of $H 3 K 27 M$-detection by ddPCR was about $90 \%$ in both CSF and plasma [35], panel sequencing appears to be more sensitive in CSF [83]. In general, ctDNA was found to be higher in CSF as compared to blood but, nonetheless, Panditharatna et al. could show that plasma-derived ctDNA levels are related to therapy and recurrence [35]. These first studies on brain stem glioma have also demonstrated that other mutations in genes such as ACVR1, IDH1 or TP53 can be reliably detected [35,83]. Apart from point mutations, gene fusions (e.g., NTRK1/2/3, ALK, ROS1) have been found in a subset of pediatric glioma and could also serve as biomarkers for the respective targeted therapeutics which are already approved. However, studies investigating this aspect in pediatric brain tumors are still lacking. Last, copy number aberrations (CNA) such as amplification of MYC/PDGFRA or deletion of CDKN2A/PTEN are frequently found in high-grade glioma and could also serve for disease monitoring. Regarding miRNAs, one study has already shown that miR-21, miR-15b, miR-23a, and miR-146b are elevated in the serum of pilocytic astrocytoma patients and that the level correlated with tumor size and therapy response [84]. Sensitivity and specificity of this approach were $86 \%$ and $100 \%$, respectively. With respect to protein detection a study investigating elevated levels of bFGF and TIMP3 in urine demonstrated $98 \%$ specificity for pilocytic astrocytoma whereas levels in the urine of medulloblastoma, high-grade glioma or non-tumor patients were negative.

\subsection{Medulloblastoma}

Molecular subgroups of medulloblastoma are well established and can be robustly determined via their distinct DNA methylation patterns [92]. Metastatic medulloblastoma usually spreads within the ventricular system making CSF a very promising biofluid for disease monitoring. Consequently, analysis of DNA methylomes in patient body fluids could serve as a potential biomarker. Moreover, certain medulloblastoma subtypes harbor somatic alterations such as TERT Promoter-, CNNB1, PTCH1 or other mutations which could be leveraged for liquid biopsy monitoring [15]. In addition, characteristic CNA including monosomy 6, GLI2-, MYCN-, of MYC amplifications are also good candidates [93]. Apart from genomic aberration, we have recently shown that CSF of medulloblastoma patients is also characterized by a distinct lipid profile which may be used as a biomarker [85]. Corroboratively, prostaglandin D2 synthase (PDG2S) has been shown to be reduced in CSF of medulloblastoma patients [86]. In contrast, insulin-like growth factor binding-protein 3 (IGFBP3) has been shown to be enriched [87]. With respect to miRNAs, we and others have already shown that medulloblastomas exhibit specific miRNA signatures [94,95] but their feasibility for liquid biopsy detection warrants further investigation. 


\subsection{Ependymoma}

Similar to medulloblastoma, ependymoma subgroups identified by DNA methylation patterns are well-established biomarkers [96] and thus represent an ideal candidate for liquid biopsy biomarkers. Apart from genome-wide methylation patterns, TERT promoter methylation has also been suggested as a potential biomarker in ependymoma which could be detected via ctDNA [97]. With respect to supratentorial ependymoma, gene fusions of RELA- and $Y A P$ are frequent somatic events which harbor potential for detection in body fluids [98]. In some cases even in posterior fossa ependymomas somatic mutations (H3K27M) may serve as biomarker [99]. The utility of ddPCR for detection of spinal ependymoma in adult patients has already been investigated but led to mixed results as ctDNA could not be reliably detected [100]. Importantly, selected CNAs such as the gain of chromosome 1q or 5p are also associated with dismal outcomes in ependymoma $[97,98]$ and could also serve as biomarkers.

\subsection{Rare Entities}

Molecular dissection across the landscape of pediatric brain tumors has uncovered numerous novel tumor entities with specific genomic alterations which could be used for liquid biopsy monitoring. Atypical teratoid rhaboid tumors (ATRT) are characterized by mutations or deletion within SMARCB1 and would be both accessible to liquid biopsy technologies. Moreover, they comprise diverse subtypes which can be determined by DNA methylation analysis [101]. On a protein level, osteopontin has been shown to be elevated in plasma and CSF of ATRT patients and a rise in level is associated with tumor recurrence [87].

Embryonal tumors with multilayered rosettes (ETMR) is another rare pediatric brain tumor type which harbors either a characteristic focal amplification of the C19MC-cluster or mutations in DICER1 [102], both genetic events potentially suitable for liquid biopsy analysis via ctDNA.

Next, CNS high-grade neuroepithelial tumor with genetic alterations in either BCOR (HGNET-BCOR), FOXR1 (HGNET-FOXR1) or MN1 (HGNET-MN1) are newly described subtypes all characterized by distinct molecular alterations [14]. Apart from their specific methylation profile, analysis of genomic aberrations such as internal-tandem duplications in the case of CNS HGNET-BCOR could be suitable for liquid biopsy detection.

\section{Conclusions}

Over the past decade, interest in biological markers isolated from patient body fluids have emerged in the scientific world and have already revolutionized the diagnosis and tumor surveillance of certain entities. However, there are still multiple pitfalls to bypass, beginning with the pre-analytical workflow of the sample processing up to the sensitivity, stability and reliability of the potential biomarkers. The first studies have already shown that this approach is also feasible for pediatric brain tumors providing potential biomarkers and further development is currently ongoing. However, the costs of the equipment for liquid biopsy techniques are still expensive and the establishment of a routine liquid biopsy lab in each center currently appears uneconomical. Consequently, centralized liquid biopsy analysis would be a feasible strategy to ensure broad availability of these methods. In addition, certain techniques such as electrochemical biosensors also harbor the potential for decentralized diagnostics in the future. Taken together, liquid biopsy could offer a more precise and comprehensive diagnosis and monitoring of pediatric brain tumors in the future, in particular in guiding personalized anti-cancer therapies, but further efforts are required until liquid biopsies can be integrated into the clinical routine and patient care.

Author Contributions: Conceptualization, S.M. and J.G.; Writing, S.M. and J.G.; Visualization, S.M. and J.G.; Funding Acquisition, S.M. and J.G. All authors have read and agreed to the published version of the manuscript.

Funding: Open Access Funding by the Austrian Science Fund (FWF). 
Acknowledgments: The generation of this review was supported by the Austrian Science fund (to S.M., I3194-B26), the "Verein unser_kind" and a Comprehensive Cancer Center Research Grant der Initiative Krebsforschung MedUni Wien (to S.M.).

Conflicts of Interest: The authors declare no conflict of interest.

\section{References}

1. Ostrom, Q.T.; Cioffi, G.; Gittleman, H.; Patil, N.; Waite, K.; Kruchko, C.; Barnholtz-Sloan, J.S. CBTRUS Statistical Report: Primary Brain and Other Central Nervous System Tumors Diagnosed in the United States in 2012-2016. Neuro Oncol. 2019, 21, v1-v100. [CrossRef] [PubMed]

2. Udaka, Y.T.; Packer, R.J. Pediatric Brain Tumors. Neurol. Clin. 2018, 36, 533-556. [CrossRef] [PubMed]

3. Packer, R.J.; Gurney, J.G.; Punyko, J.A.; Donaldson, S.S.; Inskip, P.D.; Stovall, M.; Yasui, Y.; Mertens, A.C.; Sklar, C.A.; Nicholson, H.S.; et al. Long-Term Neurologic and Neurosensory Sequelae in Adult Survivors of a Childhood Brain Tumor: Childhood Cancer Survivor Study. J. Clin. Oncol. 2003, 21, 3255-3261. [CrossRef] [PubMed]

4. Louis, D.N.; Perry, A.; Reifenberger, G.; Von Deimling, A.; Figarella-Branger, D.; Cavenee, W.K.; Ohgaki, H.; Wiestler, O.D.; Kleihues, P.; Ellison, D.W. The 2016 World Health Organization Classification of Tumors of the Central Nervous System: A summary. Acta Neuropathol. 2016, 131, 803-820. [CrossRef]

5. Galardi, A.; Colletti, M.; Di Paolo, V.; Vitullo, P.; Antonetti, L.; Russo, I.; Di Giannatale, A. Exosomal MiRNAs in Pediatric Cancers. Int. J. Mol. Sci. 2019, 20, 4600. [CrossRef]

6. Bounajem, M.T.; Karsy, M.; Jensen, R.L. Liquid biopsies for the diagnosis and surveillance of primary pediatric central nervous system tumors: A review for practicing neurosurgeons. Neurosurg. Focus 2020, 48, E8. [CrossRef]

7. Azad, T.D.; Jin, M.C.; Bernhardt, L.J.; Bettegowda, C. Liquid biopsy for pediatric diffuse midline glioma: A review of circulating tumor DNA and cerebrospinal fluid tumor DNA. Neurosurg. Focus 2020, 48, E9. [CrossRef]

8. Fehnel, K.P.; Duggins-Warf, M.; Zurakowski, D.; McKee-Proctor, M.; Majumder, R.; Raber, M.; Han, X.; Smith, E.R. Using urinary bFGF and TIMP3 levels to predict the presence of juvenile pilocytic astrocytoma and establish a distinct biomarker signature. J. Neurosurg. Pediatr. 2016, 18, 396-407. [CrossRef]

9. Kool, M.; Korshunov, A.; Remke, M.; Jones, D.T.W.; Schlanstein, M.; Northcott, P.A.; Cho, Y.-J.; Koster, J.; Meeteren, A.S.-V.; Van Vuurden, D.; et al. Molecular subgroups of medulloblastoma: An international meta-analysis of transcriptome, genetic aberrations, and clinical data of WNT, SHH, Group 3, and Group 4 medulloblastomas. Acta Neuropathol. 2012, 123, 473-484. [CrossRef]

10. Korshunov, A.; Remke, M.; Kool, M.; Hielscher, T.; Northcott, P.A.; Williamson, D.; Pfaff, E.; Witt, H.; Jones, D.T.W.; Ryzhova, M.; et al. Biological and clinical heterogeneity of MYCN-amplified medulloblastoma. Acta Neuropathol. 2012, 123, 515-527. [CrossRef]

11. Kool, M.; Koster, J.; Bunt, J.; Hasselt, N.E.; Lakeman, A.; Van Sluis, P.; Troost, D.; Meeteren, N.A.Y.S.-V.; Caron, H.N.; Cloos, J.; et al. Integrated Genomics Identifies Five Medulloblastoma Subtypes with Distinct Genetic Profiles, Pathway Signatures and Clinicopathological Features. PLoS ONE 2008, 3, e3088. [CrossRef] [PubMed]

12. Jones, D.T.W.; Banito, A.; Grünewald, T.G.P.; Haber, M.; Jäger, N.; Kool, M.; Milde, T.; Molenaar, J.J.; Nabbi, A.; Pugh, T.J.; et al. Molecular characteristics and therapeutic vulnerabilities across paediatric solid tumours. Nat. Rev. Cancer 2019, 19, 420-438. [CrossRef] [PubMed]

13. Taylor, M.D.; Northcott, P.A.; Korshunov, A.; Remke, M.; Cho, Y.-J.; Clifford, S.C.; Eberhart, C.G.; Parsons, D.W.; Rutkowski, S.; Gajjar, A.; et al. Molecular subgroups of medulloblastoma: The current consensus. Acta Neuropathol. 2012, 123, 465-472. [CrossRef] [PubMed]

14. Sturm, D.; Orr, B.A.; Toprak, U.H.; Hovestadt, V.; Jones, D.T.W.; Capper, D.; Sill, M.; Buchhalter, I.; Northcott, P.A.; Leis, I.; et al. New Brain Tumor Entities Emerge from Molecular Classification of CNS-PNETs. Cell 2016, 164, 1060-1072. [CrossRef]

15. Northcott, P.A.; Buchhalter, I.; Morrissy, A.S.; Hovestadt, V.; Weischenfeldt, J.; Ehrenberger, T.; Gröbner, S.; Segura-Wang, M.; Zichner, T.; Rudneva, V.A.; et al. The whole-genome landscape of medulloblastoma subtypes. Nat. Cell Biol. 2017, 547, 311-317. [CrossRef] 
16. Patel, R.; Ramkissoon, S.H.; Ross, J.; Weintraub, L. Tumor mutational burden and driver mutations: Characterizing the genomic landscape of pediatric brain tumors. Pediatr. Blood Cancer 2020, 67, e28338. [CrossRef]

17. Filbin, M.G.; Tirosh, I.; Hovestadt, V.; Shaw, M.L.; Escalante, L.E.; Mathewson, N.D.; Neftel, C.; Frank, N.; Pelton, K.; Hebert, C.M.; et al. Developmental and oncogenic programs in H3K27M gliomas dissected by single-cell RNA-seq. Science 2018, 360, 331-335. [CrossRef]

18. Fontanilles, M.; Duran-Peña, A.; Idbaih, A. Liquid Biopsy in Primary Brain Tumors: Looking for Stardust! Curr. Neurol. Neurosci. Rep. 2018, 18, 13. [CrossRef]

19. Le Rhun, E.; Seoane, J.; Salzet, M.; Soffietti, R.; Weller, M. Liquid biopsies for diagnosing and monitoring primary tumors of the central nervous system. Cancer Lett. 2020, 480, 24-28. [CrossRef]

20. Best, M.G.; Sol, N.; Zijl, S.; Reijneveld, J.C.; Wesseling, P.; Wurdinger, T. Liquid biopsies in patients with diffuse glioma. Acta Neuropathol. 2015, 129, 849-865. [CrossRef]

21. McEwen, A.E.; Leary, S.E.S.; Lockwood, C.M. Beyond the Blood: CSF-Derived cfDNA for Diagnosis and Characterization of CNS Tumors. Front. Cell Dev. Biol. 2020, 8, 45. [CrossRef] [PubMed]

22. Epple, L.M.; Griffiths, S.G.; Dechkovskaia, A.M.; Dusto, N.L.; White, J.; Ouellette, R.J.; Anchordoquy, T.J.; Bemis, L.T.; Graner, M.W. Medulloblastoma Exosome Proteomics Yield Functional Roles for Extracellular Vesicles. PLoS ONE 2012, 7, e42064. [CrossRef] [PubMed]

23. Colletti, M.; Di Paolo, V.; Galardi, A.; Milano, G.M.; Mastronuzzi, A.; Locatelli, F.; Di Giannatale, A.; Colletti, V.D.P.M. Nano-Delivery in Pediatric Tumors: Looking Back, Moving Forward. Anti-Cancer Agents Med. Chem. 2017, 17, 1328-1343. [CrossRef] [PubMed]

24. Yang, Y.-P.; Nguyen, P.N.N.; Ma, H.-I.; Ho, W.-J.; Chen, J.-T.; Chien, Y.; Yarmishyn, A.A.; Huang, P.-I.; Lo, W.-L.; Wang, C.-Y.; et al. Tumor Mesenchymal Stromal Cells Regulate Cell Migration of Atypical Teratoid Rhabdoid Tumor through Exosome-Mediated miR155/SMARCA4 Pathway. Cancers 2019, 11, 720. [CrossRef] [PubMed]

25. Túzesi, Á.; Kling, T.; Wenger, A.; Lunavat, T.R.; Jang, S.C.; Rydenhag, B.; Lötvall, J.; Pollard, S.M.; Danielsson, A.; Carén, H. Pediatric brain tumor cells release exosomes with a miRNA repertoire that differs from exosomes secreted by normal cells. Oncotarget 2017, 8, 90164-90175. [CrossRef] [PubMed]

26. Barile, L.; Vassalli, G. Exosomes: Therapy delivery tools and biomarkers of diseases. Pharmacol. Ther. 2017, 174, 63-78. [CrossRef] [PubMed]

27. Bookland, M.; Gillan, E.; Song, X.; Kolmakova, A. Peripheral circulation miRNA expression of pediatric brain tumors and its relation to tumor miRNA expression levels. J. Neurosurg. Pediatr. 2020, 26, 136-144. [CrossRef] [PubMed]

28. Xiao, F.; Lv, S.; Zong, Z.; Wu, L.; Tang, X.; Kuang, W.; Zhang, P.; Li, X.; Fu, J.; Xiao, M.; et al. Cerebrospinal fluid biomarkers for brain tumor detection: Clinical roles and current progress. Am. J. Transl. Res. 2020, 12, 1379-1396. [PubMed]

29. Sin-Chan, P.; Mumal, I.; Suwal, T.; Ho, B.; Fan, X.; Singh, I.; Du, Y.; Lu, M.; Patel, N.; Torchia, J.; et al. A C19MC-LIN28A-MYCN Oncogenic Circuit Driven by Hijacked Super-enhancers Is a Distinct Therapeutic Vulnerability in ETMRs: A Lethal Brain Tumor. Cancer Cell 2019, 36, 51-67. [CrossRef] [PubMed]

30. Kopkova, A.; Sana, J.; Fadrus, P.; Slaby, O. Cerebrospinal fluid microRNAs as diagnostic biomarkers in brain tumors. Clin. Chem. Lab. Med. 2018, 56, 869-879. [CrossRef]

31. Wang, X.; Holgado, B.L.; Ramaswamy, V.; Mack, S.; Zayne, K.; Remke, M.; Wu, X.; Garzia, L.; Daniels, C.; Kenney, A.M.; et al. miR miR on the wall, who's the most malignant medulloblastoma miR of them all? Neuro Oncol. 2017, 20, 313-323. [CrossRef] [PubMed]

32. Santangelo, A.; Tamanini, A.; Cabrini, G.; Dechecchi, M.C. Circulating microRNAs as emerging non-invasive biomarkers for gliomas. Ann. Transl. Med. 2017, 5, 277. [CrossRef] [PubMed]

33. Joshi, P.; Jallo, G.; Perera, R.J. In silico analysis of long non-coding RNAs in medulloblastoma and its subgroups. Neurobiol. Dis. 2020, 141, 104873. [CrossRef] [PubMed]

34. Huang, T.Y.; Piunti, A.; Lulla, R.R.; Qi, J.; Horbinski, C.M.; Tomita, T.; James, C.D.; Shilatifard, A.; Saratsis, A.M. Detection of Histone $\mathrm{H} 3$ mutations in cerebrospinal fluid-derived tumor DNA from children with diffuse midline glioma. Acta Neuropathol. Commun. 2017, 5, 1-12. [CrossRef] [PubMed] 
35. Panditharatna, E.; Kilburn, L.B.; Aboian, M.S.; Kambhampati, M.; Gordish-Dressman, H.; Magge, S.N.; Gupta, N.; Myseros, J.S.; Hwang, E.I.; Kline, C.; et al. Clinically Relevant and Minimally Invasive Tumor Surveillance of Pediatric Diffuse Midline Gliomas Using Patient-Derived Liquid Biopsy. Clin. Cancer Res. 2018, 24, 5850-5859. [CrossRef] [PubMed]

36. Castel, D.; Philippe, C.; Calmon, R.; Le Dret, L.; Truffaux, N.; Boddaert, N.; Pagès, M.; Taylor, K.R.; Saulnier, P.; Lacroix, L.; et al. Histone H3F3A and HIST1H3B K27M mutations define two subgroups of diffuse intrinsic pontine gliomas with different prognosis and phenotypes. Acta Neuropathol. 2015, 130, 815-827. [CrossRef] [PubMed]

37. Gojo, J.; Pavelka, Z.; Zapletalova, D.; Schmook, M.T.; Mayr, L.; Madlener, S.; Kyr, M.; Vejmelkova, K.; Smrcka, M.; Czech, T.; et al. Personalized Treatment of H3K27M-Mutant Pediatric Diffuse Gliomas Provides Improved Therapeutic Opportunities. Front. Oncol. 2020, 9. [CrossRef]

38. García-Romero, N.; Carrión-Navarro, J.; Areal-Hidalgo, P.; De Méndivil, A.O.; Asensi-Puig, A.; Madurga, R.; Núñez-Torres, R.; Gonzalez-Neira, A.; Belda-Iniesta, C.; González-Rumayor, V.; et al. BRAF V600E Detection in Liquid Biopsies from Pediatric Central Nervous System Tumors. Cancers 2019, 12, 66. [CrossRef]

39. Bonnomet, A.; Syne, L.; Brysse, A.; Feyereisen, E.; Thompson, E.W.; Noël, A.; Foidart, J.-M.; Birembaut, P.; Polette, M.; Gilles, C. A dynamic in vivo model of epithelial-to-mesenchymal transitions in circulating tumor cells and metastases of breast cancer. Oncogene 2011, 31, 3741-3753. [CrossRef]

40. Cong, H.; Ju, S.; Wang, X.; Cong, H. Advances in liquid biopsy using circulating tumor cells and circulating cell-free tumor DNA for detection and monitoring of breast cancer. Clin. Exp. Med. 2019, 19, 271-279. [CrossRef]

41. Plaks, V.; Koopman, C.D.; Werb, Z. Circulating Tumor Cells. Science 2013, 341, 1186-1188. [CrossRef] [PubMed]

42. Alix-Panabières, C.; Pantel, K. Challenges in circulating tumour cell research. Nat. Rev. Cancer 2014, 14, 623-631. [CrossRef] [PubMed]

43. Jahr, S.; Hentze, H.; Englisch, S.; Hardt, D.; Fackelmayer, F.O.; Hesch, R.D.; Knippers, R. DNA fragments in the blood plasma of cancer patients: Quantitations and evidence for their origin from apoptotic and necrotic cells. Cancer Res. 2001, 61, 1659-1665. [PubMed]

44. Jeppesen, D.K.; Fenix, A.M.; Franklin, J.L.; Higginbotham, J.N.; Zhang, Q.; Zimmerman, L.J.; Liebler, D.C.; Ping, J.; Liu, Q.; Evans, R.; et al. Reassessment of Exosome Composition. Cell 2019, 177, 428-445. [CrossRef]

45. Li, J.-H.; He, Z.; Lin, F.-H.; Chen, Z.-H.; Yang, S.-Y.; Duan, H.; Jiang, X.; Al-Nahari, F.; Zhang, X.-H.; Wang, J.; et al. Assessment of ctDNA in CSF may be a more rapid means of assessing surgical outcomes than plasma ctDNA in glioblastoma. Mol. Cell. Probes 2019, 46, 101411. [CrossRef] [PubMed]

46. Squadrito, M.L.; Baer, C.; Burdet, F.; Maderna, C.; Gilfillan, G.D.; Lyle, R.; Ibberson, M.; De Palma, M. Endogenous RNAs Modulate MicroRNA Sorting to Exosomes and Transfer to Acceptor Cells. Cell Rep. 2014, 8, 1432-1446. [CrossRef]

47. Valadi, H.; Ekström, K.; Bossios, A.; Sjöstrand, M.; Lee, J.J.; Tvall, J.O.L.O. Exosome-mediated transfer of mRNAs and microRNAs is a novel mechanism of genetic exchange between cells. Nat. Cell Biol. 2007, 9, 654-659. [CrossRef]

48. Montecalvo, A.; Larregina, A.T.; Shufesky, W.J.; Stolz, D.B.; Sullivan, M.L.G.; Karlsson, J.M.; Baty, C.J.; Gibson, G.A.; Erdos, G.; Wang, Z.; et al. Mechanism of transfer of functional microRNAs between mouse dendritic cells via exosomes. Blood 2012, 119, 756-766. [CrossRef]

49. Ramachandran, S.; Palanisamy, V. Horizontal transfer of RNAs: Exosomes as mediators of intercellular communication. Wiley Interdiscip. Rev. RNA 2012, 3, 286-293. [CrossRef]

50. Hergenreider, E.; Heydt, S.; Tréguer, K.; Boettger, T.; Horrevoets, A.J.G.; Zeiher, A.M.; Scheffer, M.P.; Frangakis, A.S.; Yin, X.; Mayr, M.; et al. Atheroprotective communication between endothelial cells and smooth muscle cells through miRNAs. Nat. Cell Biol. 2012, 14, 249-256. [CrossRef]

51. Li, Y.; Cheng, Q.; Hu, G.; Deng, T.; Wang, Q.; Zhou, J.; Su, X. Extracellular vesicles in mesenchymal stromal cells: A novel therapeutic strategy for stroke (Review). Exp. Ther. Med. 2018, 15, 4067-4079. [CrossRef]

52. Lee, Y.; El Andaloussi, S.; Wood, M.J.A. Exosomes and microvesicles: Extracellular vesicles for genetic information transfer and gene therapy. Hum. Mol. Genet. 2012, 21, R125-R134. [CrossRef]

53. Rashed, M.H.; Bayraktar, E.; Helal, G.K.; Abd-Ellah, M.F.; Amero, P.; Chavez-Reyes, A.; Rodriguez-Aguayo, C. Exosomes: From Garbage Bins to Promising Therapeutic Targets. Int. J. Mol. Sci. 2017, 18, 538. [CrossRef] [PubMed] 
54. Shahabipour, F.; Banach, M.; Sahebkar, A. Exosomes as nanocarriers for siRNA delivery: Paradigms and challenges. Arch. Med. Sci. 2016, 6, 1324-1326. [CrossRef] [PubMed]

55. Haney, M.J.; Klyachko, N.L.; Zhao, Y.; Gupta, R.; Plotnikova, E.G.; He, Z.; Patel, T.; Piroyan, A.; Sokolsky, M.; Kabanov, A.V.; et al. Exosomes as drug delivery vehicles for Parkinson's disease therapy. J. Control. Release 2015, 207, 18-30. [CrossRef] [PubMed]

56. Zhao, Z.; Zlokovic, B.V. Remote control of BBB: A tale of exosomes and microRNA. Cell Res. 2017, 27, 849-850. [CrossRef] [PubMed]

57. Yang, T.; Martin, P.; Fogarty, B.; Brown, A.; Schurman, K.; Phipps, R.; Yin, V.P.; Lockman, P.; Bai, S. Exosome Delivered Anticancer Drugs Across the Blood-Brain Barrier for Brain Cancer Therapy in Danio Rerio. Pharm. Res. 2015, 32, 2003-2014. [CrossRef] [PubMed]

58. Guduric-Fuchs, J.; O'Connor, A.; Camp, B.; O’Neill, C.L.; Medina, R.J.; Simpson, D.A. Selective extracellular vesicle-mediated export of an overlapping set of microRNAs from multiple cell types. BMC Genom. 2012, 13, 357. [CrossRef]

59. Zhang, Z.G.; Chopp, M. Exosomes in stroke pathogenesis and therapy. J. Clin. Investig. 2016, 126, $1190-1197$. [CrossRef]

60. Cappelletti, V.; Appierto, V.; Tiberio, P.; Fina, E.; Callari, M.; Daidone, M.G. Circulating Biomarkers for Prediction of Treatment Response. J. Natl. Cancer Inst. Monogr. 2015, 2015, 60-63. [CrossRef]

61. Batkai, S.; Thum, T. Analytical approaches in microRNA therapeutics. J. Chromatogr. B Analyt. Technol. Biomed. Life Sci. 2014, 964, 146-152. [CrossRef] [PubMed]

62. Ono, S.; Lam, S.; Nagahara, M.; Hoon, D.S. Circulating microRNA Biomarkers as Liquid Biopsy for Cancer Patients: Pros and Cons of Current Assays. J. Clin. Med. 2015, 4, 1890-1907. [CrossRef] [PubMed]

63. Mitchell, P.S.; Parkin, R.K.; Kroh, E.M.; Fritz, B.R.; Wyman, S.K.; Pogosova-Agadjanyan, E.L. Circulating microRNAs as stable blood-based markers for cancer detection. Proc. Natl. Acad. Sci. USA 2008, 105, 10513-10518. [CrossRef] [PubMed]

64. Hicks, S.D.; Johnson, J.; Carney, M.C.; Bramley, H.; Olympia, R.P.; Loeffert, A.C.; Thomas, N.J. Overlapping MicroRNA Expression in Saliva and Cerebrospinal Fluid Accurately Identifies Pediatric Traumatic Brain Injury. J. Neurotrauma 2018, 35, 64-72. [CrossRef]

65. El Messaoudi, S.; Rolet, F.; Mouliere, F.; Thierry, A.R. Circulating cell free DNA: Preanalytical considerations. Clin. Chim. Acta 2013, 424, 222-230. [CrossRef]

66. Rossi, G.; Ignatiadis, M. Promises and Pitfalls of Using Liquid Biopsy for Precision Medicine. Cancer Res. 2019, 79, 2798-2804. [CrossRef]

67. Gorges, T.M.; Penkalla, N.; Schalk, T.; Joosse, S.A.; Riethdorf, S.; Tucholski, J.; Lücke, K.; Wikman, H.; Jackson, S.M.; Brychta, N.; et al. Enumeration and Molecular Characterization of Tumor Cells in Lung Cancer Patients Using a Novel In Vivo Device for Capturing Circulating Tumor Cells. Clin. Cancer Res. 2016, 22, 2197-2206. [CrossRef]

68. Nevel, K.S.; Wilcox, J.A.; Robell, L.J.; Umemura, Y. The Utility of Liquid Biopsy in Central Nervous System Malignancies. Curr. Oncol. Rep. 2018, 20, 60. [CrossRef]

69. Sesé, M.; Somoza, R.; Maestu, I.; Ureste, M.M.; Sanchez, A.; Cordoba, J.F.; Sansano, I.; Venturas, G.; Cajal, S.R.Y.; Hernández-Losa, J. Validation of Cell-Free DNA Collection Tubes for Determination of EGFR Mutation Status in Liquid Biopsy from NSCLC Patients. Oncol. Ther. 2019, 7, 131-139. [CrossRef]

70. Kerachian, M.A.; Azghandi, M.; Javadmanesh, A.; Ghaffarzadegan, K.; Mozaffari-Jovin, S. Selective capture of plasma cell-free tumor DNA on magnetic beads: A sensitive and versatile tool for liquid biopsy. Cell. Oncol. 2020, 43, 949-956. [CrossRef]

71. Thakur, B.K.; Zhang, H.; Becker, A.; Matei, I.; Huang, Y.; Costa-Silva, B.; Zheng, Y.; Hoshino, A.; Brazier, H.; Xiang, J.; et al. Double-stranded DNA in exosomes: A novel biomarker in cancer detection. Cell Res. 2014, 24, 766-769. [CrossRef] [PubMed]

72. Giulietti, M.; Occhipinti, G. Employment of Exosomes for Liquid Biopsies. Transl. Biomed. 2015, 6. [CrossRef]

73. Balzano, F.; Deiana, M.; Giudici, S.D.; Oggiano, A.; Baralla, A.; Pasella, S.; Mannu, A.; Pescatori, M.; Porcu, B.; Fanciulli, G.; et al. miRNA Stability in Frozen Plasma Samples. Molecules 2015, 20, 19030-19040. [CrossRef] [PubMed]

74. Chen, M.; Zhao, H. Next-generation sequencing in liquid biopsy: Cancer screening and early detection. Human Genom. 2019, 13, 1-10. [CrossRef] 
75. Plagnol, V.; Woodhouse, S.; Howarth, K.; Lensing, S.; Smith, M.; Epstein, M.; Madi, M.; Smalley, S.; Leroy, C.; Hinton, J.; et al. Analytical validation of a next generation sequencing liquid biopsy assay for high sensitivity broad molecular profiling. PLoS ONE 2018, 13, e0193802. [CrossRef]

76. Gale, D.; Lawson, A.R.J.; Howarth, K.; Madi, M.; Durham, B.; Smalley, S.; Calaway, J.; Blais, S.; Jones, G.; Clark, J.; et al. Development of a highly sensitive liquid biopsy platform to detect clinically-relevant cancer mutations at low allele fractions in cell-free DNA. PLoS ONE 2018, 13, e0194630. [CrossRef]

77. Yi, X.; Ma, J.; Guan, Y.; Chen, R.; Yang, L.; Xia, X. The feasibility of using mutation detection in ctDNA to assess tumor dynamics. Int. J. Cancer 2017, 140, 2642-2647. [CrossRef]

78. Bellassai, N.; Spoto, G. Biosensors for liquid biopsy: Circulating nucleic acids to diagnose and treat cancer. Anal. Bioanal. Chem. 2016, 408, 7255-7264. [CrossRef]

79. Hong, C.-Y.; Chen, X.; Liu, T.; Li, J.; Yang, H.-H.; Chen, J.-H.; Chen, G.-N. Ultrasensitive electrochemical detection of cancer-associated circulating microRNA in serum samples based on DNA concatamers. Biosens. Bioelectron. 2013, 50, 132-136. [CrossRef]

80. Das, J.; Ivanov, I.N.; Montermini, L.; Rak, J.; Sargent, E.H.; Kelley, S.O. An electrochemical clamp assay for direct, rapid analysis of circulating nucleic acids in serum. Nat. Chem. 2015, 7, 569-575. [CrossRef]

81. Bruch, R.; Baaske, J.; Chatelle, C.; Meirich, M.; Madlener, S.; Weber, W.; Dincer, C.; Urban, G.A. CRISPR/Cas13a-Powered Electrochemical Microfluidic Biosensor for Nucleic Acid Amplification-Free miRNA Diagnostics. Adv. Mater. 2019, 31, e1905311. [CrossRef] [PubMed]

82. Bruch, R.; Urban, G.A.; Dincer, C. CRISPR/Cas Powered Multiplexed Biosensing. Trends Biotechnol. 2019, 37, 791-792. [CrossRef] [PubMed]

83. Pan, C.; Diplas, B.H.; Chen, X.; Wu, Y.; Xiao, X.; Jiang, L.; Geng, Y.; Xu, C.; Sun, Y.; Zhang, P.; et al. Molecular profiling of tumors of the brainstem by sequencing of CSF-derived circulating tumor DNA. Acta Neuropathol. 2019, 137, 297-306. [CrossRef] [PubMed]

84. Bookland, M.; Tang-Schomer, M.; Gillan, E.; Kolmakova, A. Circulating serum oncologic miRNA in pediatric juvenile pilocytic astrocytoma patients predicts mural nodule volume. Acta Neurochir. 2018, 160, 1571-1581. [CrossRef]

85. Reichl, B.; Niederstaetter, L.; Boegl, T.; Neuditschko, B.; Bileck, A.; Gojo, J.; Buchberger, W.; Peyrl, A.; Gerner, C. Determination of a Tumor-Promoting Microenvironment in Recurrent Medulloblastoma: A Multi-Omics Study of Cerebrospinal Fluid. Cancers 2020, 12, 1350. [CrossRef]

86. Rajagopal, M.U.; Hathout, Y.; Macdonald, T.J.; Kieran, M.; Gururangan, S.; Blaney, S.M.; Phillips, P.; Packer, R.; Gordish-Dressman, H.; Rood, B.R. Proteomic profiling of cerebrospinal fluid identifies prostaglandin D2 synthase as a putative biomarker for pediatric medulloblastoma: A pediatric brain tumor consortium study. Proteomics 2011, 11, 935-943. [CrossRef]

87. De Bont, J.M.; Van Doorn, J.; Reddingius, R.E.; Graat, G.H.; Passier, M.M.; Boer, M.L.D.; Pieters, R. Various components of the insulin-like growth factor system in tumor tissue, cerebrospinal fluid and peripheral blood of pediatric medulloblastoma and ependymoma patients. Int. J. Cancer 2008, 123, 594-600. [CrossRef]

88. Kao, C.L.; Chiou, S.H.; Ho, D.M.T.; Chen, Y.J.; Liu, R.S.; Lo, C.W.; Tsai, F.T.; Chen, Y.J.; Liu, R.S.; Wen, C.; et al. Elevation of Plasma and Cerebrospinal Fluid Osteopontin Levels in Patients With Atypical Teratoid/Rhabdoid Tumor. Am. J. Clin. Pathol. 2005, 123, 297-304. [CrossRef]

89. Nakano, Y.; Watanabe, Y.; Honda-Kitahara, M.; Yamagishi, Y.; Niizuma, H.; Niihori, T.; Sasahara, Y.; Sonoda, Y.; Narita, Y.; Nagane, M.; et al. Utility of a bridged nucleic acid clamp for liquid biopsy: Detecting BRAF V600E in the cerebrospinal fluid of a patient with brain tumor. Pediatr. Blood Cancer 2020, 67, 28651. [CrossRef]

90. Kaley, T.; Touat, M.; Subbiah, V.; Hollebecque, A.; Rodon, J.; Lockhart, A.C.; Keedy, V.; Bielle, F.; Hofheinz, R.-D.; Joly, F.; et al. BRAF Inhibition in BRAFV600-Mutant Gliomas: Results From the VE-BASKET Study. J. Clin. Oncol. 2018, 36, 3477-3484. [CrossRef]

91. Zhang, J.; Yao, T.-W.; Hashizume, R.; Hariono, S.; Barkovich, K.J.; Fan, Q.-W.; Prados, M.; James, C.D.; Weiss, W.A.; Nicolaides, T.P. Combined BRAFV600E and MEK blockade for BRAFV600E-mutant gliomas. J. Neuro Oncol. 2017, 131, 495-505. [CrossRef] [PubMed]

92. Hovestadt, V.; Jones, D.T.W.; Picelli, S.; Wang, W.; Kool, M.; Northcott, P.A.; Sultan, M.; Stachurski, K.; Ryzhova, M.; Warnatz, H.-J.; et al. Decoding the regulatory landscape of medulloblastoma using DNA methylation sequencing. Nat. Cell Biol. 2014, 510, 537-541. [CrossRef] [PubMed] 
93. Ramaswamy, V.; Remke, M.; Bouffet, E.; Bailey, S.; Clifford, S.C.; Doz, F.; Kool, M.; Dufour, C.; Vassal, G.; Milde, T.; et al. Risk stratification of childhood medulloblastoma in the molecular era: The current consensus. Acta Neuropathol. 2016, 131, 821-831. [CrossRef] [PubMed]

94. Braoudaki, M.; Lambrou, G.I.; Giannikou, K.; Milionis, V.; Stefanaki, K.; Birks, D.K.; Prodromou, N.; Kolialexi, A.; Kattamis, A.; Spiliopoulou, C.A.; et al. Microrna expression signatures predict patient progression and disease outcome in pediatric embryonal central nervous system neoplasms. J. Hematol. Oncol. 2014, 7, 1-18. [CrossRef] [PubMed]

95. Senfter, D.; Samadaei, M.; Mader, R.M.; Gojo, J.; Peyrl, A.; Krupitza, G.; Kool, M.; Sill, M.; Haberler, C.; Ricken, G.; et al. High impact of miRNA-4521 on FOXM1 expression in medulloblastoma. Cell Death Dis. 2019, 10, 1-15. [CrossRef]

96. Pajtler, K.W.; Mack, S.C.; Ramaswamy, V.; Smith, C.A.; Witt, H.; Smith, A.; Hansford, J.R.; Von Hoff, K.; Wright, K.D.; Hwang, E.; et al. The current consensus on the clinical management of intracranial ependymoma and its distinct molecular variants. Acta Neuropathol. 2017, 133, 5-12. [CrossRef]

97. Gojo, J.; Lötsch, D.; Spiegl-Kreinecker, S.; Pajtler, K.W.; Neumayer, K.; Korbel, P.; Araki, A.; Brandstetter, A.; Mohr, T.; Hovestadt, V.; et al. Telomerase activation in posterior fossa group A ependymomas is associated with dismal prognosis and chromosome 1q gain. Neuro Oncol. 2017, 19, 1183-1194. [CrossRef]

98. Pajtler, K.W.; Witt, H.; Sill, M.; Jones, D.T.; Hovestadt, V.; Kratochwil, F.; Wani, K.; Tatevossian, R.; Punchihewa, C.; Johann, P.; et al. Molecular Classification of Ependymal Tumors across All CNS Compartments, Histopathological Grades, and Age Groups. Cancer Cell 2015, 27, 728-743. [CrossRef]

99. Pajtler, K.W.; Wen, J.; Sill, M.; Lin, T.; Orisme, W.; Tang, B.; Hübner, J.-M.; Ramaswamy, V.; Jia, S.; Dalton, J.D.; et al. Molecular heterogeneity and CXorf67 alterations in posterior fossa group A (PFA) ependymomas. Acta Neuropathol. 2018, 136, 211-226. [CrossRef]

100. Connolly, I.D.; Li, Y.; Pan, W.; Johnson, E.; You, L.; Vogel, H.; Ratliff, J.; Gephart, M.H. A pilot study on the use of cerebrospinal fluid cell-free DNA in intramedullary spinal ependymoma. J. Neuro Oncol. 2017, 135, 29-36. [CrossRef]

101. Ho, B.; Johann, P.D.; Grabovska, Y.; Andrianteranagna, M.J.D.D.; Yao, F.P.; Frühwald, M.; Hasselblatt, M.; Bourdeaut, F.; Williamson, D.; Huang, A.; et al. Molecular subgrouping of atypical teratoid/rhabdoid tumors-A reinvestigation and current consensus. Neuro Oncol. 2019, 22, 613-624. [CrossRef] [PubMed]

102. Lambo, S.; Gröbner, S.N.; Rausch, T.; Waszak, S.M.; Schmidt, C.; Gorthi, A.; Romero, J.C.; Mauermann, M.; Brabetz, S.; Krausert, S.; et al. The molecular landscape of ETMR at diagnosis and relapse. Nat. Cell Biol. 2019, 576, 274-280. [CrossRef] [PubMed]

Publisher's Note: MDPI stays neutral with regard to jurisdictional claims in published maps and institutional affiliations.

(C) 2020 by the authors. Licensee MDPI, Basel, Switzerland. This article is an open access article distributed under the terms and conditions of the Creative Commons Attribution (CC BY) license (http://creativecommons.org/licenses/by/4.0/). 